\title{
Factors influencing the internet banking adoption decision in North Cyprus: an evidence from the partial least square approach of the structural equation modeling
}

\author{
Hiba Alhassany ${ }^{1 *}$ (D) and Faisal Faisal ${ }^{2,3}$
}

\footnotetext{
* Correspondence:

Hiba.alhassany@yahoo.com

${ }^{1}$ Department of Accounting and

Finance, Cyprus International

University, Nicosia 99040, Northern Cyprus

Full list of author information is

available at the end of the article
}

\begin{abstract}
Purpose: This paper aims to examine how the adoption decision of the internet banking in North Cyprus would be affected based on the following dimensions; the technology features, the personal characteristics, the social environment and the expected risk.

Design/methodology/approach: A self-administered survey was conducted with 291 participants responded to it. The partial least square approach of the structural equation modeling (PLS-SEM) is employed to investigate the direct effects of the proposed factors on the adoption decision. Additionally, the mediation test is used to examine indirect effects.

Findings: Results showed that even though the participants appreciated the benefits of the online banking as the perceived usefulness factor exerts the greatest direct effect, they would rather use clear and easy-to-use websites, adding to that their assessments of the usefulness of these services are significantly influenced by the surrounding people's views and prior experience. This is demonstrated by the total effects of the perceived ease of use and the subjective norm factors, which are greater than the direct effect of the perceived usefulness factor since both of these factors have significant direct and indirect effects mediated by the perceived usefulness factor. The negative impact of the perceived risk factor is weak compared to the previous factors. While the personal innovativeness factor showed the weakest effect among the proposed factors.
\end{abstract}

Keywords: Behavioral theories, Technology adoption, TAM, Subjective norm, Personal innovativeness, Perceived risk, Partial least square, Structural equation modeling

\section{Introduction}

The recent substantial developments in technologies and innovations have stimulated the community and businesses to adopt the latest technology because of its countless advantages that have eased and improved the business environment in the recent decades. This has drawn the attention of the researchers to investigate for models which

C The Author(s). 2018 Open Access This article is distributed under the terms of the Creative Commons Attribution 4.0 International License (http://creativecommons.org/licenses/by/4.0/), which permits unrestricted use, distribution, and reproduction in any medium, provided you give appropriate credit to the original author(s) and the source, provide a link to the Creative Commons license, and indicate if changes were made. 
determine the main factors that can encourage people to adopt these technologies. The technology acceptance model (TAM) known as a parsimonious model comprises the main technology's features that would encourage users to adopt it, furthermore, the verifiability of TAM has been confirmed by researchers, and the generalization of its findings has been established as well, since the technology acceptance model has been used to examine the adoption of different types of the information technology with a heterogeneous group of subjects through many points of time. (Chintalapati and Daruri, 2017).

TAM has been widely addressed in literature particularly related to the internet banking services, taking into account that the internet banking has created a competitive environment for banks in the market and enabled them to reach and serve a broader range of customers with less cost. The internet banking has enhanced the transparency of the banks' financial statements disclosure and it gives banks an easy tool to market its services (Nasri and Charfeddine, 2012).

Considering the significance of the internet banking services in the current scenerio, this paper contributes to the better understand about the internet banking adoption decision by extending it to the technology acceptance model (TAM). Furthermore, technology acceptance model will be integrated it into a new model that consists of the main four influential dimensions that have been proposed singly or bilaterally in the previous literature. The key influential dimensions that will be addressed in this study are the technology features dimension, the personality dimension, the social dimension, and the uncertainty about the usage consequences (i.e. the expected risks).

This study is undertaken in North Cyprus which recently becomes a destination for many international students, real estate investors and tourists, what causes a remarkable advance in its the banking sector in corresponding to the increased demand for banking services by newcomers. In general the economy of North Cyprus depends on the service sector that includes education and tourism, and according to a recent study on customer satisfaction and loyalty in banking sector in North Cyprus showed that the vast majority of the TRNC citizens who have participated in this study prefer visiting bank branches, due to security issues and friendly service provided by the banks' personnel. Furthermore, the quiet lifestyle in this small part of the island, which is free of congestion, and the accessibility of all facilities within a short time, in addition to the socializing nature of the TRNC people who they live in a cohesive society in which the personal relationships is highly valued, These special characteristics have reflected on the banks' working environment, as most customers prefer visiting the bank branch in their neighbourhood and establishing good relations with the bank personnel rather than using the alternative banking channels (Ozatac, et al., 2016).

This highlights the importance of this paper that aims to provide important insights about the potential customers and helps the banks' managers in North Cyprus in enhancing their marketing strategy and benefiting from internet banking advantages. Furthermore, the diverse community in North Cyprus which has come from different countries stimulates the banking system competitivity with many improved services and facilitates its integration with the global financial system.

Moreover, to the best of our knowledge, this paper is the first in the literature that investigates the extension of the technology acceptance model (TAM) in North Cyprus. Additionally, this study also analyzed four influential dimensions in one model that 
have not been utilized together in one model before in the earlier literature in these regards. Additionally, the proposed model in this paper is a mixed model that distinguishes between reflective and formative constructs, since the subjective norms (SN) construct that represents the social dimension is measured by formative indicators as it is a result of interpersonal communication process and it is formed by the external influences (Rogers, 2003). The other constructs (i.e. PU, PEOU, INO, R and IN) are measured by reflective indicators.

\section{Literature review}

Two approaches have been followed in the adoption literature, in the first approach technology's features are the main factor in the adoption decisions, while the second highlights the functional and psychological aspects that influence the adoption decision (Yousafzai, 2012).

In the internet banking literature, the technology acceptance model (TAM) has widely represented the first approach, with TAM main elements the perceived ease of use (PEOU) and the perceived usefulness (PU) researchers could capture the internet banking services features Giovanis, et al. (2012); Kalaiarasi and Srividya (2012); Al-Fahim (2012); Yoon and Steege (2013); Wu et al.(2014); Kumar and Govindaluri (2014); Bashir and Madhavaiah (2015); Rawashdeh (2015). However, few studies have indirectly indicated to these factors and substituted them by other factors such as the Importance of Internet Banking needs, compatibility, and convenience factors in (Oruç and Tatar, 2016), while Kesharwani and Radhakrishna (2013) addressed the perceived benefit and the services compatibility factors, and Jalil et al. (2014) addressed the website characteristics factor. In this paper, the perceived ease of use (PEOU) and the perceived usefulness (PU) will represent the technology features dimension.

The researchers in the second approach have examined the effect of the personal dimension on the internet banking adoption, Kumar and Madhumohan (2014) addressed the Awareness factor and the computer self-efficacy factor which is addressed by Kesharwani and Radhakrishna (2013), while Yoon and Steege (2013) addressed the personal openness for any new experience factor. In this study, the Personal innovativeness factor will be addressed in order to investigate the effect of the personal dimension on the internet banking adoption decision.

Along with the personal dimension, the social pressures has received a special attention by researchers in order investigate its influence on the individual compliance to use internet banking services Bashir and Madhavaiah (2015); Kumar and Madhumohan Govindaluri, (2014); Kesharwani and Radhakrishna (2013). In their turn, Yoon \& Steege (2013) proposed the green concern factor as a representative of the social pressure, while Wu et al. (2014) referred to the social influence in the form of subjective norm factor, which it will be addressed in the current paper as well. Last but not least, the expected trisks factor has represented the reluctant attitude to adopt the internet banking services due to the uncertainty of usage consequences.

In general, the perceived risk has been addressed as a whole one factor, however, some researcher have decomposed it into several types such like performance risk, social risk, time risk, financial risk and security risk Fadare et al. (2016); Giovanis, et al. (2012). On the other hand, some researchers have only addressed few types of risk Yoon and Steege (2013); Jalil et al. (2014) addressed the security concerns factor, Awni 
Rawashdeh (2015) addressed the privacy risk, while Kesharwani \& Radhakrishna (2013) addressed the performance risk, hacking, and fraud. In this study, the perceived risk factor as a whole one factor will represent the uncertainty of usage consequences dimension.

The following table summarizes the previous studies focusing on the proposed factors, the study subjects, and its place, in addition to the analytical methods that have been employed to obtain the study findings.

\begin{tabular}{|c|c|c|c|c|}
\hline Authors name & The proposed factors & $\begin{array}{l}\text { The study } \\
\text { subjects }\end{array}$ & Place & The analytical approach \\
\hline Giovanis, et al. (2012). & $\begin{array}{l}\text { Perceived usefulness, } \\
\text { perceived ease of use, } \\
\text { perceived risk (decomposed), } \\
\text { the compatibility of the } \\
\text { service. }\end{array}$ & $\begin{array}{l}\text { Banks' } \\
\text { customers }\end{array}$ & Greece & $\begin{array}{l}\text { Partial least square for } \\
\text { Structure equation } \\
\text { modeling (PLS-SEM) }\end{array}$ \\
\hline $\begin{array}{l}\text { Kalaiarasi and Srividya } \\
\text { (2012). }\end{array}$ & $\begin{array}{l}\text { Perceived usefulness, } \\
\text { perceived ease of use, } \\
\text { perceived risk. }\end{array}$ & $\begin{array}{l}\text { University } \\
\text { students }\end{array}$ & India & $\begin{array}{l}\text { Structure equation } \\
\text { modeling (SEM) }\end{array}$ \\
\hline Al-Fahim, (2012). & $\begin{array}{l}\text { Perceived usefulness, } \\
\text { perceived ease of use, } \\
\text { perceived risk, trust }\end{array}$ & $\begin{array}{l}\text { University } \\
\text { students }\end{array}$ & Malaysia & $\begin{array}{l}\text { Structure equation } \\
\text { modeling (SEM) }\end{array}$ \\
\hline $\begin{array}{l}\text { Kesharwani and } \\
\text { Radhakrishna (2013). }\end{array}$ & $\begin{array}{l}\text { The perceived benefit, } \\
\text { performance risk, hacking, } \\
\text { fraud, computer self-efficacy, } \\
\text { services compatibility, social } \\
\text { influence, pricing concerns. }\end{array}$ & $\begin{array}{l}\text { Internet } \\
\text { banking users }\end{array}$ & India & Multiple regression \\
\hline $\begin{array}{l}\text { Yoon and Steege } \\
\text { (2013). }\end{array}$ & $\begin{array}{l}\text { Perceived usefulness, } \\
\text { perceived ease of use, } \\
\text { openness, green } \\
\text { concerns(SN), and security } \\
\text { concerns. }\end{array}$ & $\begin{array}{l}\text { University } \\
\text { students }\end{array}$ & USA & $\begin{array}{l}\text { Partial least square for } \\
\text { Structure equation } \\
\text { modeling (PLS-SEM) }\end{array}$ \\
\hline Jalil et al. (2014) & $\begin{array}{l}\text { Trust, security, website } \\
\text { characteristics. }\end{array}$ & $\begin{array}{l}\text { Banks' } \\
\text { customers }\end{array}$ & Malaysia & $\begin{array}{l}\text { Structure equation } \\
\text { modeling (SEM) }\end{array}$ \\
\hline Wu M, et al. (2014) & $\begin{array}{l}\text { Perceived usefulness, } \\
\text { perceived ease of use, } \\
\text { perceived risk, perceived } \\
\text { behavioural control, the } \\
\text { subjective norm. }\end{array}$ & $\begin{array}{l}\text { Banks' } \\
\text { customers }\end{array}$ & China & $\begin{array}{l}\text { Partial least square for } \\
\text { Structure equation } \\
\text { modeling (PLS-SEM) }\end{array}$ \\
\hline $\begin{array}{l}\text { Kumar and } \\
\text { Madhumohan. (2014). }\end{array}$ & $\begin{array}{l}\text { Perceived usefulness, } \\
\text { perceived ease of use, social } \\
\text { effect, awareness, quality of } \\
\text { internet connection, } \\
\text { computer self-efficacy }\end{array}$ & $\begin{array}{l}\text { Banks' } \\
\text { customers }\end{array}$ & India & $\begin{array}{l}\text { Structure equation } \\
\text { modeling (SEM) }\end{array}$ \\
\hline $\begin{array}{l}\text { Bashir and Madhavaiah } \\
\text { (2015) }\end{array}$ & $\begin{array}{l}\text { Perceived usefulness, } \\
\text { perceived ease of use, } \\
\text { perceived risk, social effect, } \\
\text { trust, enjoyment, user-friendly } \\
\text { website. }\end{array}$ & $\begin{array}{l}\text { University } \\
\text { students }\end{array}$ & India & $\begin{array}{l}\text { Structure equation } \\
\text { modeling (SEM) }\end{array}$ \\
\hline Rawashdeh (2015) & $\begin{array}{l}\text { Perceived usefulness, } \\
\text { perceived ease of use, privacy }\end{array}$ & Accountants & Jordan & $\begin{array}{l}\text { Structure equation } \\
\text { modeling (SEM) }\end{array}$ \\
\hline Fadare et al. (2016) & $\begin{array}{l}\text { Performance risk, social risk, } \\
\text { time risk, financial risk and } \\
\text { security risk. }\end{array}$ & $\begin{array}{l}\text { University } \\
\text { students }\end{array}$ & Malaysia & Multiple regression \\
\hline Oruç and Tatar (2016) & $\begin{array}{l}\text { Importance of Internet } \\
\text { Banking Needs, Compatibility, } \\
\text { Convenience, and } \\
\text { Communication. }\end{array}$ & $\begin{array}{l}\text { University } \\
\text { Academic staff }\end{array}$ & Turkey & $\begin{array}{l}\text { Structure equation } \\
\text { modeling (SEM) }\end{array}$ \\
\hline
\end{tabular}




\begin{tabular}{|c|c|c|c|c|}
\hline Authors name & The proposed factors & $\begin{array}{l}\text { The study } \\
\text { subjects }\end{array}$ & Place & The analytical approach \\
\hline Boateng et al. (2016) & $\begin{array}{l}\text { Websites' social feature, Trust, } \\
\text { Compatibility, Online } \\
\text { customer services, Ease of } \\
\text { use }\end{array}$ & Bank customers & Ghana & $\begin{array}{l}\text { Structure equation } \\
\text { modeling (SEM) }\end{array}$ \\
\hline
\end{tabular}

\section{The study conceptual framework}

Figure 1 illustrates the conceptual framework of this study demonstrating that the intention to use internet banking would be affected based on the following dimensions: the technology features dimension represented by the technology acceptance model (TAM) with its two elements the perceived usefulness (PU) and the perceived ease of use (PEOU), the personality dimension represented by the personal innovativeness factor (INO), the social dimension represented by the subjective norm (SN) factor, and the uncertainty about the usage consequences dimension represented by the expected risk factor (R).

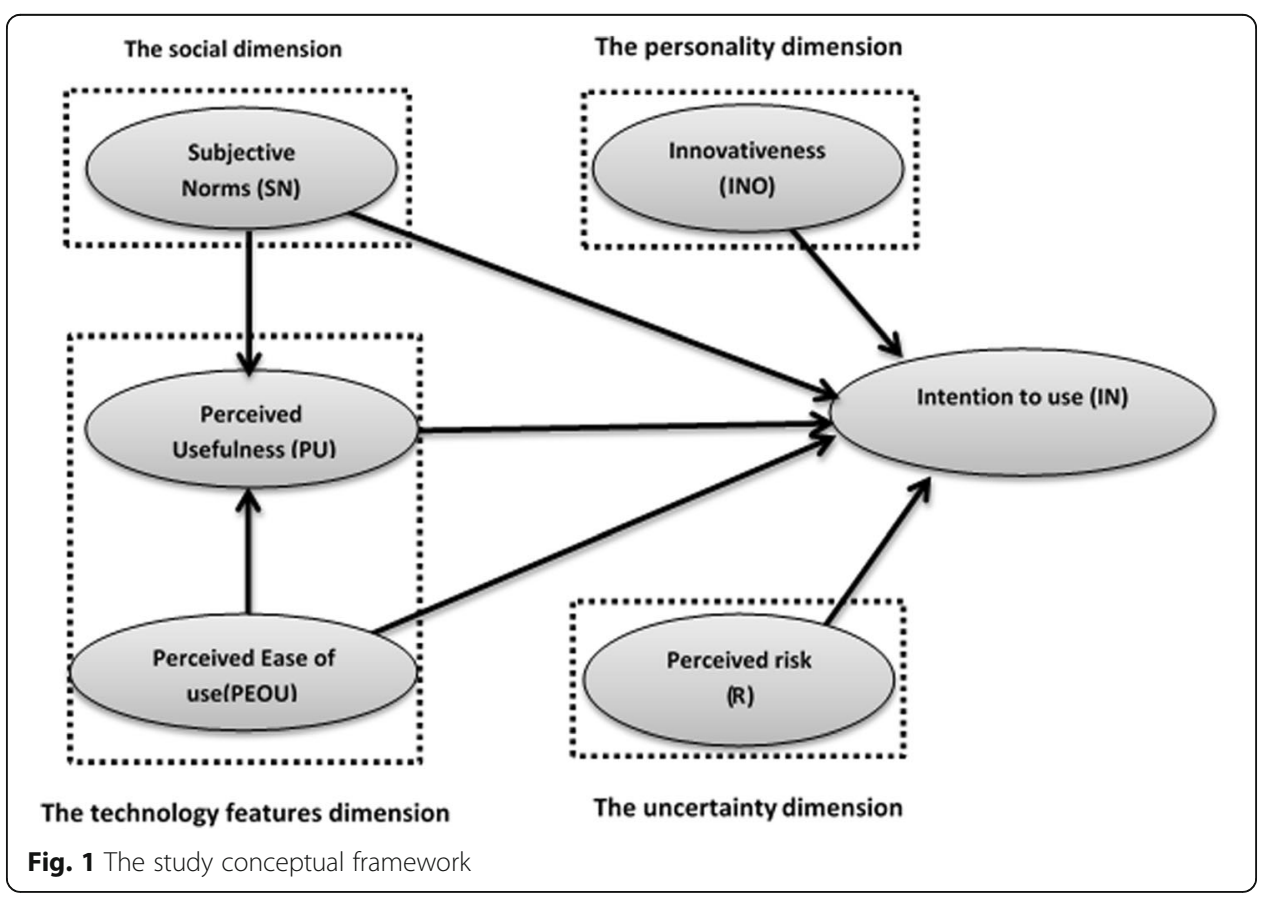

\section{The study hypotheses}

In order to investigate and determine the effects of the proposed dimensions on the behavioral intention to adopt internet-banking services, the researcher will examine the following hypotheses:

The perceived usefulness

The perceived usefulness factor refers to the users' beliefs that adopting internet services would help them improving their productivity and their performance 
efficiency as well. Thus If they believe that they would benefit from using internet banking, the more likely it would positively affect their intentions to use it (Chuttur, M. Y., 2009).

Hypothesis one: The perceived usefulness factor is positively associated with the customers' intention to adopt the internet banking services.

\section{The perceived ease of use}

The perceived ease of use factor refers to the users' perspectives and their evaluations of the internet banking usage difficulty, that would affect their intention to adopt such services, so as far as these services are easy to use and do not cause any confusion, it could encourage customer to adopt these type of services (Chuttur, M. Y., 2009).

Hypothesis two: The perceived ease of use factor is positively associated with the customers' intention to adopt the internet banking services.

The perceived ease of use factor would also indirectly influence the students' intention to use internet banking services, considering that students would value the beneficial outcomes from using the internet banking if it is easy to handle and does not require much effort to use it (Chuttur, M. Y., 2009).

Hypothesis three: The perceived ease of use factor indirectly influences the customers' intention to use internet banking through the perceived usefulness factor.

\section{Subjective norm}

The subjective norm factor refers to the social environment effects on the customers' intentions to use internet banking, since the surrounding people's beliefs and thoughts about this type of services would motivate the customer to use it, as well it could influence the customers' perspectives about how it would be useful if they used these services (Willis, T. J., 2008).

Hypothesis four: The subjective norm factor is positively associated with the customers' intention to adopt the internet banking services.

Hypothesis five: The subjective norm factor indirectly influences the customers' intention to use internet banking through the perceived usefulness factor.

\section{The perceived risk}

The perceived risk refers to the uncertainty degree that relates to the unfavorable consequences of using the internet banking, the most concerned issues that could negatively influence the customers' decisions to adopt internet banking services are; the security and privacy issues and the potential financial losses and the ability to correct the occurring mistakes (Kesharwani, A., \& Singh Bisht, S., 2012).

Hypothesis six: The perceived risk factor is negatively associated with the customers' intention to adopt the internet banking services.

\section{The personal innovativeness}

The personal innovativeness factor refers to the individual's readiness to experience a new innovation, according to the personal innovativeness the individuals in one society can be classified into five categories the innovators and the early adopters individuals,these two categories are the Pioneers in adopting any new innovation, then they are followed by 
those individuals in the early majority and late majority categories, while the individuals in the laggards category are the latest adopters (Rogers, E.M., 2003).

Hypothesis seven: The personal innovativeness factor is positively associated with the customers' intention to adopt the internet banking services.

\section{Sample size determination}

To ensure the sample size adequacy and since this research is employing the partial least square approach of the structural equation modeling, the minimum sample size requirement is determined based on the paths number, i.e. the number of arrows that point to the latent variable constructs, this rule is proposed by Marcoulides and Saunders (2006), who they have recommended 80 cases as a minimum sample size in corresponding to 7 arrows. Although the partial least square approach has the ability to handle small sample sizes, researchers have suggested that sample size between 100 and 300 would be preferred when a path modeling is carrying out (Wong, 2013).

\section{The research methodology}

Sekaran (2003) have shown that conducting a survey would be useful to describe the characteristics of a large population. In this regards, 300 questionnaires were distributed randomly among the international students in North Cyprus. A total of 291 completed questionnaires have been received back to be addressed in the study sample. Appendix illustrates the questionnaire form.

\section{Rationale of choosing partial least square approach of the structural equation modeling (PLS-SEM)}

Recently the partial least square approach of structural equation modeling has become one of the most popular multivariate analytical methods, due to its capability to deal with the non-normal data distributions which are the case in the social sciences data, in addition to its relatively small sample size requirements and high flexibility to deal with formative indicators (Hair, 2014). PLS-SEM has been used in wide variety of the social sciences studies recently, such as marketing research, management information systems, operations, strategic management and accounting. (Monecke and Leisch, 2012).

Moreover, PLS-SEM has been developed to deal with the data inadequacy issues such like heterogeneity. Also, it has provided the researcher with suitable means to conduct a simultaneous test for multiple relationships among the variables in the case of complex and multivariate phenomena (Hair et al., 2014).

Based on that employing the Partial Least Square Approach for the Structural Equation modeling (PLS-SEM) would be more suitable to achieve the study objectives. 


\section{Data analysis software}

Mainly in this study, the researcher has used the well-known Statistical Package for Social Science software (SPSS) v.20 and SmartPLS (version.3.2.4) software tools for partial least square Structural Equation modeling (PLS-SEM) (Ringle et al., 2015).

\section{Establish construct validity and reliability of reflective constructs}

\section{Exploratory factor analysis (the initial test)}

The initial tests have been conducted based on (31) reflective indicators and 5 formative indicators using SmartPLS software, the program has been set to 300 maximum iterations with stop criterion of 7 . Figure 2 shows the initial test results demonstrating that 9 of reflective indicators have relatively low loadings with their corresponding construct.

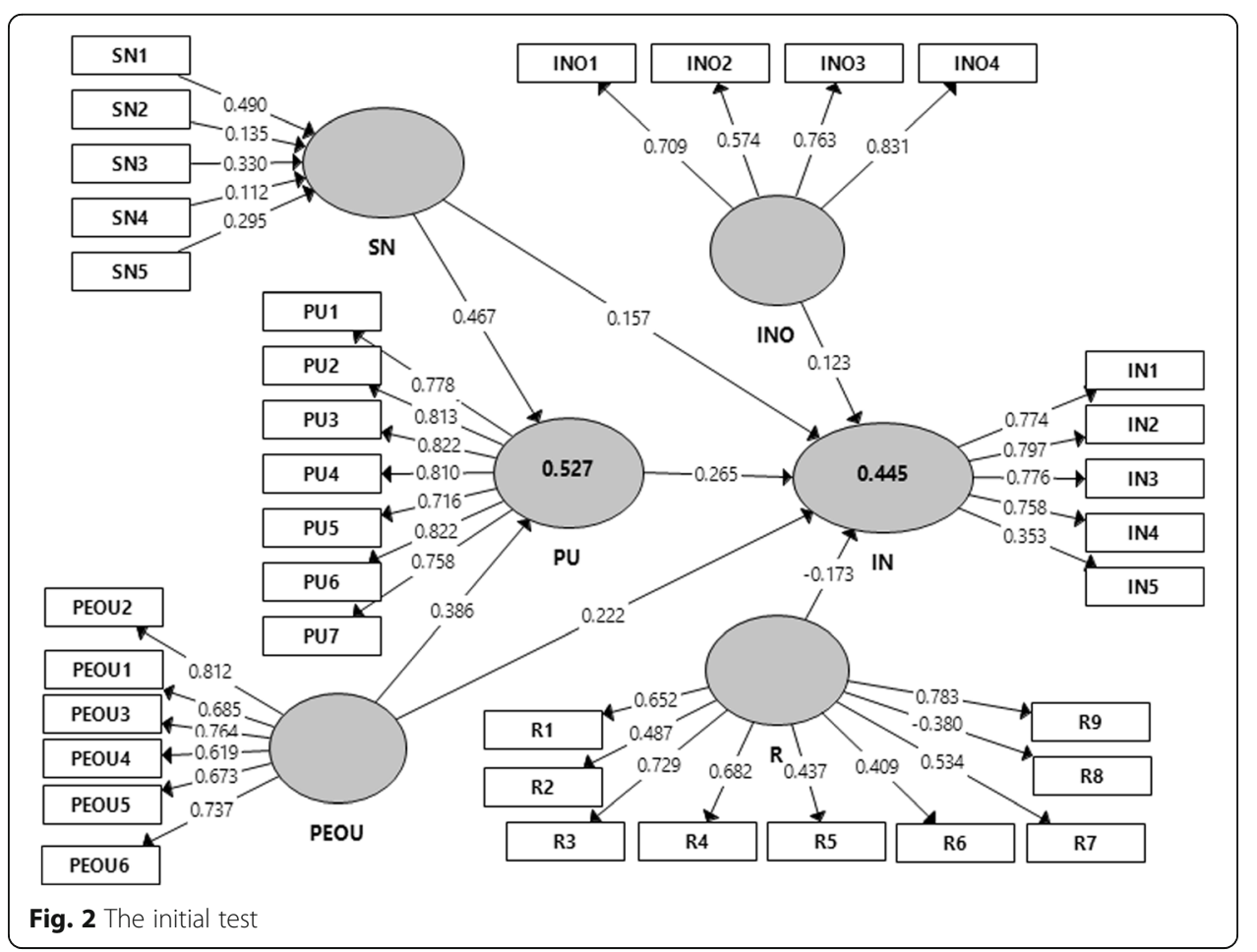


The initial test has shown that removing (9) reflective indicators would improve the quality and the predictive relevance of the structural model, and achieve noticeable improvements in the internal consistency, convergent validity and discriminant validity of the reflective measurement constructs. Consequently, the researcher has removed the following indicators one at a time R8, R6, R5, R2, R7, IN5, INO2, PEOU4, and PEUO5.

Figure 3 illustrates the structural equation model for this study after conducting the required modification.

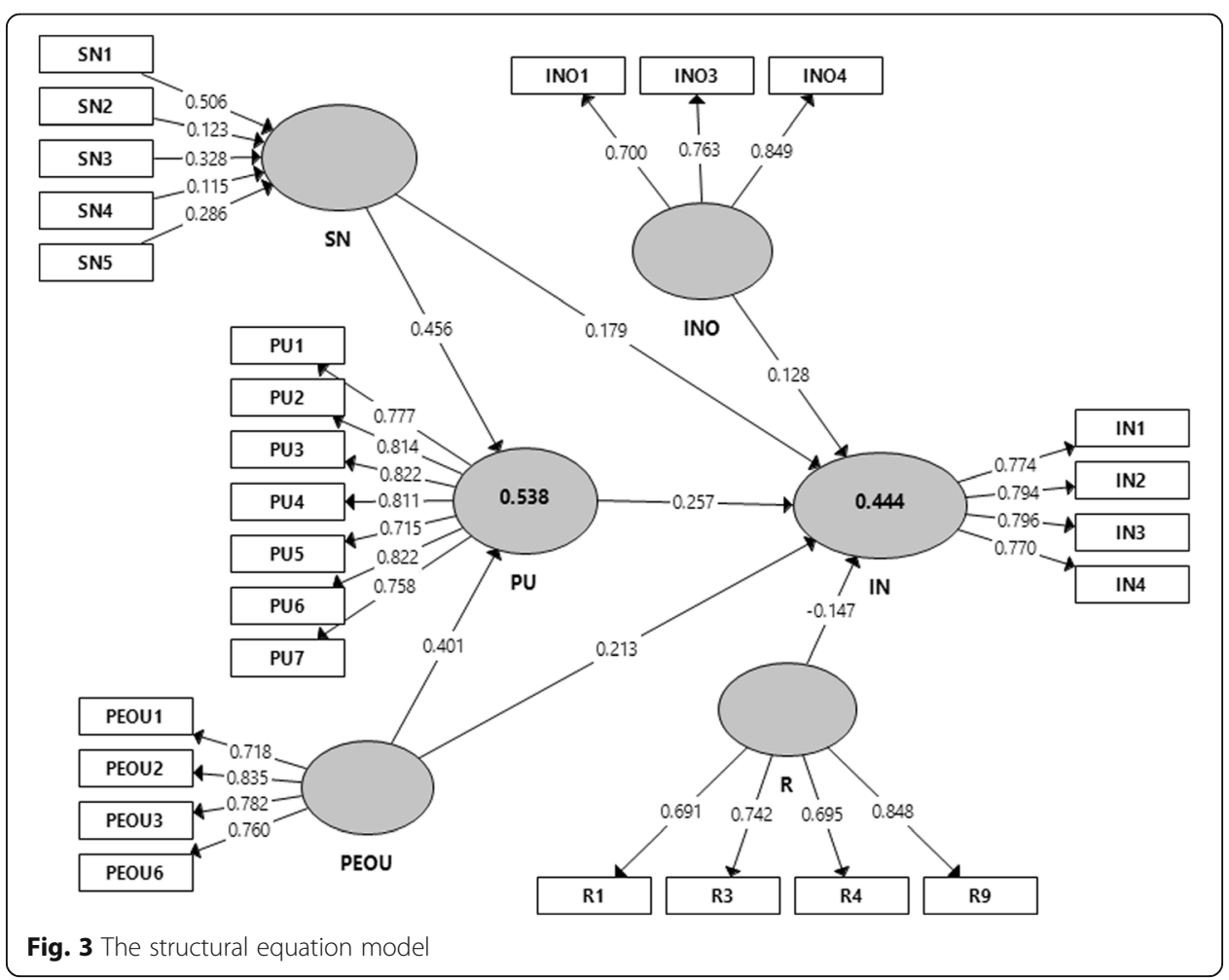

Reliability

\section{Indicator reliability}

Table 1 shows that indicator reliability values are ranged between $(0.477-0.720)$ so it can be concluded that the indicator reliability is confirmed by Hulland and Richard (1999).

Table 1 The indicator reliability

\begin{tabular}{llll}
\hline Construct (Latent variable) & Indicators & Loadings & Indicator Reliability (loadings $^{2}$ ) \\
\hline The intention to use (IN) & IN1 & 0.774 & 0.599 \\
& IN2 & 0.794 & 0.630 \\
& IN3 & 0.796 & 0.633 \\
& IN4 & 0.770 & 0.592 \\
The personal innovativeness (INO) & INO1 & 0.700 & 0.490 \\
& INO3 & 0.763 & 0.582
\end{tabular}


Table 1 The indicator reliability (Continued)

\begin{tabular}{llll}
\hline Construct (Latent variable) & Indicators & Loadings & Indicator Reliability (loadings $^{2}$ ) \\
\hline \multirow{3}{*}{ The perceived ease of use (PEOU) } & INO4 & 0.849 & 0.720 \\
& PEOU1 & 0.718 & 0.515 \\
PEOU2 & 0.835 & 0.697 \\
The perceived usefulness (PU) & PEOU3 & 0.782 & 0.611 \\
& PEOU6 & 0.760 & 0.577 \\
PU1 & 0.777 & 0.603 \\
PU2 & 0.814 & 0.662 \\
The perceived risk (R) & PU3 & 0.822 & 0.675 \\
& PU4 & 0.811 & 0.657 \\
PU5 & 0.715 & 0.511 \\
& PU6 & 0.822 & 0.675 \\
PU7 & 0.758 & 0.574 \\
& R1 & 0.691 & 0.477 \\
R3 & 0.742 & 0.550 \\
R4 & 0.695 & 0.483 \\
R9 & 0.848 & 0.719 \\
\hline
\end{tabular}

\section{Internal consistency reliability}

The composite reliability value will be addressed to examine the internal consistency for the reflective constructs, Table 2 shows the composite reliability for each construct is greater than 0.7 confirming the Internal consistency reliability (Hair et al., 2014).

Table 2 The composite reliability

\begin{tabular}{ll}
\hline Construct (Latent variable) & Composite Reliability \\
\hline The intention to adopt (IN) & 0.864 \\
The personal innovativeness (INO) & 0.816 \\
The perceived ease of use (PEOU) & 0.857 \\
The perceived usefulness (PU) & 0.920 \\
The perceived risk (R) & 0.833
\end{tabular}

\section{Validity}

\section{Convergent validity}

The average variance extracted (AVE) value for each construct is greater than the acceptable threshold of 0.5 , so it can be concluded that the convergent validity is confirmed by (Henseler et al., 2016) (Table 3).

Table 3 Average variance extracted (AVE)

\begin{tabular}{ll}
\hline Construct (Latent variable) & Average Variance Extracted (AVE) \\
\hline The intention to adopt (IN) & 0.614 \\
The personal innovativeness (INO) & 0.598 \\
The perceived ease of use (PEOU) & 0.601 \\
The perceived usefulness (PU) & 0.623 \\
The perceived risk (R) & 0.558 \\
\hline
\end{tabular}




\section{Discriminant validity}

Cross loading Table 4 demonstrates that the loadings of the construct's indicators exceed cross-loadings giving a discriminate evidence among the constructs (Voorhees et al., 2016).

Table 4 The cross loading matrix

\begin{tabular}{|c|c|c|c|c|c|c|}
\hline & IN & INO & PEOU & PU & $R$ & SN \\
\hline IN1 & 0.774 & 0.276 & 0.429 & 0.484 & -0.276 & 0.335 \\
\hline IN2 & 0.794 & 0.261 & 0.438 & 0.453 & -0.220 & 0.382 \\
\hline IN3 & 0.796 & 0.287 & 0.445 & 0.464 & -0.224 & 0.448 \\
\hline IN4 & 0.770 & 0.277 & 0.380 & 0.412 & -0.240 & 0.402 \\
\hline INO1 & 0.199 & 0.700 & 0.290 & 0.191 & 0.005 & 0.216 \\
\hline INO3 & 0.235 & 0.763 & 0.308 & 0.174 & -0.059 & 0.224 \\
\hline INO4 & 0.347 & 0.849 & 0.301 & 0.279 & -0.121 & 0.265 \\
\hline PEOU1 & 0.341 & 0.256 & 0.718 & 0.367 & -0.173 & 0.319 \\
\hline PEOU2 & 0.480 & 0.331 & 0.835 & 0.552 & -0.284 & 0.394 \\
\hline PEOU3 & 0.383 & 0.248 & 0.782 & 0.502 & -0.171 & 0.343 \\
\hline PEOU6 & 0.454 & 0.343 & 0.760 & 0.454 & -0.162 & 0.371 \\
\hline PU1 & 0.497 & 0.290 & 0.452 & 0.777 & -0.282 & 0.539 \\
\hline PU2 & 0.413 & 0.240 & 0.545 & 0.814 & -0.249 & 0.512 \\
\hline PU3 & 0.485 & 0.222 & 0.440 & 0.822 & -0.260 & 0.468 \\
\hline PU4 & 0.477 & 0.211 & 0.461 & 0.811 & -0.168 & 0.520 \\
\hline PU5 & 0.400 & 0.162 & 0.402 & 0.715 & -0.167 & 0.422 \\
\hline PU6 & 0.430 & 0.227 & 0.530 & 0.822 & -0.139 & 0.540 \\
\hline PU7 & 0.490 & 0.221 & 0.538 & 0.758 & -0.234 & 0.527 \\
\hline R1 & -0.161 & -0.046 & -0.159 & -0.108 & 0.691 & -0.081 \\
\hline R3 & -0.176 & 0.012 & -0.143 & -0.185 & 0.742 & -0.039 \\
\hline R4 & -0.179 & -0.069 & -0.182 & -0.209 & 0.695 & -0.050 \\
\hline R9 & -0.329 & -0.121 & -0.256 & -0.269 & 0.848 & -0.156 \\
\hline SN1 & 0.442 & 0.236 & 0.378 & 0.531 & -0.170 & 0.848 \\
\hline SN2 & 0.340 & 0.214 & 0.363 & 0.362 & -0.075 & 0.607 \\
\hline SN3 & 0.370 & 0.269 & 0.330 & 0.482 & -0.056 & 0.747 \\
\hline SN4 & 0.268 & 0.202 & 0.281 & 0.397 & -0.003 & 0.587 \\
\hline SN5 & 0.289 & 0.171 & 0.302 & 0.438 & -0.038 & 0.643 \\
\hline
\end{tabular}


Fornell and Larcker criterion Table 5 illustrates that the square root value of the AVE of each construct is greater than its correlation values with other constructs, confirming the discriminant validity according to Fornell and Larcker Criterion (Henseler et al., 2016).

Table 5 Fornell and Larcker criterion

\begin{tabular}{|c|c|c|c|c|c|c|}
\hline & IN & INO & PEOU & PU & R & SN \\
\hline IN & 0.784 & & & & & \\
\hline INO & 0.351 & 0.773 & & & & \\
\hline PEOU & 0.541 & 0.382 & 0.775 & & & \\
\hline PU & 0.579 & 0.287 & 0.612 & 0.789 & & \\
\hline R & -0.306 & -0.089 & -0.260 & -0.273 & 0.747 & \\
\hline SN & 0.500 & 0.306 & 0.463 & 0.642 & -0.125 & \\
\hline
\end{tabular}

The Heterotrait-Monotrait ratio of correlations (HTMT) The discriminant validity between two reflective constructs will be confirmed if the HTMT value is less than 0.90. Table 6 shows that the HTMT values have not exceeded the 0.9 thresholds so it can be concluded the discriminant validity has been established among all constructs. (Henseler et al., 2015).

Table 6 Heterotrait-Monotrait ratio (HTMT)

\begin{tabular}{lllll}
\hline & IN & INO & PEOU & PU \\
\hline IN & & & & \\
INO & 0.458 & & & \\
PEOU & 0.680 & 0.528 & & \\
PU & 0.685 & 0.352 & 0.719 & 0.317 \\
R & 0.365 & 0.133 & 0.316 & \\
\hline
\end{tabular}

\section{Establish construct validity and reliability of formative constructs}

Outer model relevance

Table 7 demonstrates the bootstrapping ${ }^{1}$ results of the outer weights of the formative construct (SN) (i.e. Paths coefficients significance tests) (Ringle et al. (2015)).

Table 7 Bootstrapping results of the outer weights

\begin{tabular}{llllll}
\hline $\begin{array}{l}\text { Original Sample } \\
(\mathrm{O})\end{array}$ & $\begin{array}{l}\text { Sample Mean } \\
(\mathrm{M})\end{array}$ & $\begin{array}{l}\text { Standard Deviation } \\
(\mathrm{STDEV})\end{array}$ & $\begin{array}{l}\text { T Statistics }(\mid \mathrm{O} / \\
\text { STDEV } \mid)\end{array}$ & $\begin{array}{l}P \\
\text { Values }\end{array}$ \\
\hline SN1 - > SN & 0.506 & 0.505 & 0.096 & 5.255 & $0.000^{* * *}$ \\
SN2 - > SN & 0.123 & 0.122 & 0.094 & 1.303 & 0.193 \\
SN3 - > SN & 0.328 & 0.324 & 0.095 & 3.447 & $0.001^{* *}$ \\
SN4 - > SN & 0.115 & 0.109 & 0.101 & 1.140 & 0.255 \\
SN5 - > SN & 0.286 & 0.280 & 0.079 & 3.624 & $0.000^{* * *}$ \\
\hline
\end{tabular}

Indicates significant paths: ${ }^{*} p<0.05,{ }^{* *} p<0.01,{ }^{* * *} p<0.001$ 
Since the outer weights of two indicators are not significant, in this case, the significance test of the outer loadings (i.e. the bivariate correlations of the formative indicators with its construct) should be conducted, Table 8 demonstrates the bootstrapping results of the outer loadings, revealing the suitability and relevance of the formative measurement model (Hair et al. 2014).

Table 8 Bootstrapping results for the outer loadings

\begin{tabular}{llllll}
\hline & Original sample (O) & Sample mean (M) & Standard deviation (STDEV) & $\begin{array}{l}\text { T Statistics } \\
(|\mathrm{O} / \mathrm{STDEV}|)\end{array}$ & $P$ Values \\
\hline SN1 - > SN & 0.848 & 0.837 & 0.055 & 15.327 & $0.000^{* * *}$ \\
SN2 - > SN & 0.607 & 0.598 & 0.078 & 7.804 & $0.000^{* * *}$ \\
SN3 - > SN & 0.747 & 0.737 & 0.058 & 12.838 & $0.000^{* * *}$ \\
SN4 - > SN & 0.587 & 0.577 & 0.085 & 6.907 & $0.000^{* * *}$ \\
SN5 - > SN & 0.643 & 0.634 & 0.067 & 9.560 & $0.000^{* * *}$ \\
\hline
\end{tabular}

Indicates significant paths: ${ }^{*} p<0.05,{ }^{* *} p<0.01,{ }^{* * *} p<0.001$

\section{Convergent validity}

The redundancy analysis will be carried out to confirm the convergent validity of the formative measurement model, Fig. 4 demonstrates the redundancy analysis results and shows that the path coefficient between the formative construct (SN) and the global item (i.e. the mean of the formative indicators) is (1) greater than the threshold 0.8 so it can be concluded that the convergent validity is established as in Hair et al. (2014).

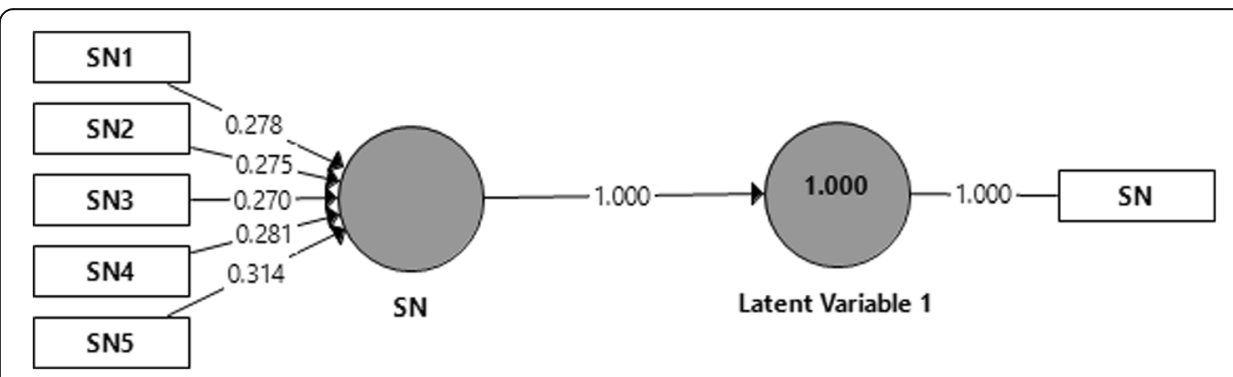

Fig. 4 The redundancy analysis

\section{The multicollinearity test}

Table 9 demonstrates the VIF value for the formative indicators and shows that VIF values are lower than threshold 5 confirming the absence of the multicollinearity problem (Hair et al., 2014) (Table 9).

Table 9 Variance inflation factor (VIF) values

\begin{tabular}{lr}
\hline Formative Indicators & VIF \\
\hline SN1 & 1.562 \\
SN2 & 1.440 \\
SN3 & 1.542 \\
SN4 & 1.422 \\
SN5 & 1.262 \\
\hline
\end{tabular}




\section{Test for common methods bias}

It is essential to conduct a test for the common methods of bias as both of endogenous and exogenous variables are collected togather using one questionair (Lowry and Gaskin, 2014). For the reflective constructs, Harman's single factor test will be used, Table 10 shows that the merged single factor explains $33.655 \%$ of the total variances in the model, this is less than the threshold $50 \%$, so it can be confirmed the absence of the common methods bias in the reflective indicators (Lowry and Gaskin, 2014).

Table $\mathbf{1 0}$ Harman's single factor test

\begin{tabular}{|c|c|c|c|c|c|c|}
\hline \multicolumn{7}{|c|}{ Total variance explained } \\
\hline \multirow[t]{2}{*}{ Component } & \multicolumn{3}{|c|}{ Initial Eigenvalues } & \multicolumn{3}{|c|}{ Extraction sums of squared loadings } \\
\hline & Total & $\%$ of Variance & Cumulative $\%$ & Total & $\%$ of Variance & Cumulative \% \\
\hline 1 & 7.404 & 33.655 & 33.655 & 7.404 & 33.655 & 33.655 \\
\hline
\end{tabular}

For the formative construct, Pearson's correlations matrix will be used to examine the correlation values between the formative indicators, Table 11 shows that there is no correlation value exceed 0.09 threshold, so it can be confirmed that there is no Common Methods Bias in the formative indicators (Lowry and Gaskin, 2014).

Table 11 Pearson's correlations matrix

\begin{tabular}{lllllll}
\hline & & SN1 & SN2 & SN3 & SN4 & SN5 \\
\hline SN1 & Pearson Correlation & 1 & $.496^{\mathrm{a}}$ & $.445^{\mathrm{a}}$ & $.378^{\mathrm{a}}$ & $.324^{\mathrm{a}}$ \\
& Sig. (2-tailed) & & .000 & .000 & .000 & .000 \\
SN2 & $\mathrm{N}$ & 291 & 291 & 291 & 291 & 291 \\
& Pearson Correlation & $.496^{\mathrm{a}}$ & 1 & $.284^{\mathrm{a}}$ & $.334^{\mathrm{a}}$ & $.357^{\mathrm{a}}$ \\
& Sig. (2-tailed) & .000 & & .000 & .000 & .000 \\
& $\mathrm{~N}$ & 291 & 291 & 291 & 291 & 291 \\
SN3 & Pearson Correlation & $.445^{\mathrm{a}}$ & $.284^{\mathrm{a}}$ & 1 & $.494^{\mathrm{a}}$ & $.360^{\mathrm{a}}$ \\
& Sig. (2-tailed) & .000 & .000 & & .000 & .000 \\
& N & 291 & 291 & 291 & 291 & 291 \\
& PN4 & $.378^{\mathrm{a}}$ & $.334^{\mathrm{a}}$ & $.494^{\mathrm{a}}$ & 1 & $.275^{\mathrm{a}}$ \\
& Sig. (2-tailed) & .000 & .000 & .000 & & .000 \\
& N & 291 & 291 & 291 & 291 & 291 \\
& Pearson & $.324^{\mathrm{a}}$ & $.357^{\mathrm{a}}$ & $.360^{\mathrm{a}}$ & $.275^{\mathrm{a}}$ & 1 \\
& Sig. (2-tailed) & .000 & .000 & .000 & .000 & \\
& N & 291 & 291 & 291 & 291 & 291 \\
\hline
\end{tabular}

Note: ${ }^{\mathrm{a}}$ suggests that correlation is significant at the 0.01 level (2-tailed) 


\section{The mediation test}

Table 12 illustrates the indirect effects of Perceived ease of use (PEOU) and Subjective Norm (SN) on the endogenous construct Intention to use (IN), these effects are mediated through the Perceived Usefulness (PU) factor.

Table 12 Indirect effects

\begin{tabular}{|c|c|c|c|c|c|c|}
\hline & IN & INO & PEOU & PU & R & SN \\
\hline \multicolumn{7}{|l|}{ IN } \\
\hline \multicolumn{7}{|l|}{ INO } \\
\hline PEOU & 0.103 & & & & & \\
\hline \multicolumn{7}{|l|}{ PU } \\
\hline \multicolumn{7}{|l|}{ R } \\
\hline SN & 0.117 & & & & & \\
\hline
\end{tabular}

Table 13 illustrates the total effects of the proposed factors (i.e. the sum of the direct and indirect effects).

Table 13 Total effects

\begin{tabular}{|c|c|c|c|c|c|c|}
\hline & IN & INO & PEOU & PU & $\mathrm{R}$ & SN \\
\hline \multicolumn{7}{|l|}{ IN } \\
\hline INO & 0.128 & & & & & \\
\hline PEOU & 0.316 & & & 0.401 & & \\
\hline PU & 0.257 & & & & & \\
\hline $\mathrm{R}$ & -0.147 & & & & & \\
\hline SN & 0.296 & & & 0.456 & & \\
\hline
\end{tabular}

The bootstrapping results in Table 14 shows that both of the direct and indirect effects of PEOU and SN on the endogenous construct Intention to use (IN) are statistically significant, revealing that the Perceived Usefulness (PU) partially mediates the effects of PEOU and SN (Nitzl et al., 2016).

Table $\mathbf{1 4}$ T.test for the direct and indirect effects

\begin{tabular}{cllll}
\hline & Original sample $(O)$ & Standard deviation (STDEV) & T Statistics $(|\mathrm{O} / \mathrm{STDEV}|)$ & $P$ Values \\
\hline Direct effects & & & & \\
PEOU - > IN & 0.213 & 0.064 & 3.342 & $0.001^{* *}$ \\
SN - IN & 0.179 & 0.068 & 2.637 & $0.008^{* *}$ \\
Indirect effects & & & & \\
PEOU - > IN & 0.103 & 0.034 & 3.075 & $0.002^{* *}$ \\
SN - > IN & 0.117 & 0.038 & 3.127 & $0.002^{* *}$ \\
\hline
\end{tabular}

Indicates significant paths: ${ }^{*} p<0.05,{ }^{* *} p<0.01,{ }^{* * *} p<0.001$ 


\section{Multicollinearity test}

The Variance Inflation Factor (VIF) values of the exogenous latent variables in the Table 15 are lower than the threshold (5), based on that it can be concluded there is no multicollinearity problem within the structural model. (Lowry and Gaskin, 2014); Ringle et al., 2015).

Table 15 the VIF values

\begin{tabular}{|c|c|c|c|c|c|c|}
\hline & IN & INO & PEOU & PU & R & SN \\
\hline INO & 1.201 & & & & & \\
\hline PEOU & 1.768 & & & 1.272 & & \\
\hline PU & 2.231 & & & & & \\
\hline R & 1.104 & & & & & \\
\hline SN & 1.769 & & & 1.272 & & \\
\hline
\end{tabular}

\section{Model fit}

The standardized root mean square residual SRMR criteria is used to ensure the absence of misspecification in the mixed model that consists of reflective and formative constructs, SRMR assesses the differences between the actual correlation matrix (observed from the sample) and the expected one (which is predicted by the model). SRMR value is equal to 0.059 , which is less than the threshold of 0.08 indicates a good fit of the model (Henseler et al., 2016).

\section{Assess the predictive power of the model} Coefficient of determination $\left(R^{2}\right)$

The five exogenous variables (INO, PEOU, PU, R, and SN) moderately explain $44.4 \%$ of the total variance in IN. Also, PEOU and SN moderately explain $53.8 \%$ of the total variance in PU. Table 16 shows small difference s between $R^{2}$ and adjusted $R^{2}$ values.

Table $16 R^{2}$ and Adjusted $R^{2}$

\begin{tabular}{lll}
\hline & R Square & R Square Adjusted \\
\hline $\mathrm{NN}$ & 0.444 & 0.434 \\
$\mathrm{PU}$ & 0.538 & 0.535 \\
\hline
\end{tabular}




\section{Effect size $\left(\mathbf{f}^{2}\right)$}

The elimination effect size of each exogenous variable on the model explanatory power is calculated in Table 17, results reveal that dropping any of the exogenous variables (INO, PEOU, PU, R, or SN) that explain (IN) has a medium effect size on its $\mathrm{R}^{2}$, since the $\mathrm{f}^{2}$ cutoff values for small effect size is $(0.02,0.15)$ for medium effect size, and $(0.3)$ for high effect size. While the elimination of either PEOU or SN and has high effect size for each of them on the $\mathrm{R}^{2}$ for (PU) (Garson, 2016).

Table $17 f^{2}$ values

\begin{tabular}{lll}
\hline & IN & PU \\
\hline IN & & \\
INO & 0.025 & \\
PEOU & 0.046 & 0.274 \\
PU & 0.053 & \\
R & 0.035 & \\
SN & 0.033 & 0.354 \\
\hline
\end{tabular}

\section{Cross-validated redundancy $\left(Q^{2}\right)$}

The blindfolding ${ }^{2}$ technique will be used in order to obtain the cross-validated redundancy values (i.e. the Stone Geisser $\mathrm{Q}^{2}$ for the endogenous reflective constructs PU, IN) (Ringle et al., 2015). Table 18 shows the Cross-validated redundancy $\left(\mathrm{Q}^{2}\right)$ values for IN and PU.

Table 18 Cross-validated redundancy $\left(Q^{2}\right)$

\begin{tabular}{ll}
\hline & $Q^{2}$ \\
\hline IN & 0.260 \\
PU & 0.329 \\
\hline
\end{tabular}

Since the $\mathrm{Q}^{2}$ values for IN and PU are 0.260 and 0.329 respectively, which is greater than 0 it can be concluded the structural model has good predictive relevance with regard to the endogenous constructs IN and PU. Garson (2016).

\section{Hypotheses test results}

The following Table 19 summarizes the hypotheses test results.

Table 19 The hypotheses test results

\begin{tabular}{lllll}
\hline Hypotheses & Corresponding path & Path coefficient & T-value & Decision \\
\hline Hypothesis one & PU $->$ IN & +0.257 & $3.472^{* *}$ & Supported \\
Hypothesis two & PEOU $->$ IN & +0.213 & $3.342^{* *}$ & Supported \\
*Hypothesis three & PEOU $->\mathrm{PU}->\mathrm{IN}$ & +0.103 & $3.075^{* *}$ & Supported \\
Hypothesis four & $\mathrm{SN}->\mathrm{N}$ & +0.179 & $2.637^{* *}$ & Supported \\
*Hypothesis five & $\mathrm{SN}->\mathrm{PU}->\mathrm{N}$ & +0.117 & $3.127^{* *}$ & Supported \\
Hypothesis six & $\mathrm{R}->\mathrm{N}$ & -0.147 & $3.575^{* * *}$ & Supported \\
Hypothesis seven & $\mathrm{NO}->\mathrm{N}$ & +0.128 & $2.582^{*}$ & Supported \\
\hline
\end{tabular}

Indicates significant paths: ${ }^{*} p<0.05,{ }^{* *} p<0.01,{ }^{* * *} p<0.001$

*The mediation Test results for the indirect effects 


\section{Conclusion}

- This study reveals that perceived usefulness (PU) factor plays an important role in influencing the internet banking adoption decision, inline with the previous literature Al-Fahim (2012); Kesharwani and Radhakrishna (2013); Kumar and Madhumohan (2014); Bashir and Madhavaiah (2015); Rawashdeh (2015). Since PU exerts the greatest direct effects compared to the other factors and partially mediates the indirect effect of the perceived ease of use (PEOU) and the subjective norm (SN) factors.

- The results of the study showed that path coefficients in PLS-SEM are standardized regression coefficients, which enables the comparison between the magnitudes of the exogenous variables effects (Jakobowicz (2006)). By comparing the total effects of the proposed factors illustrates it has been quite evident that the perceived ease of use (PEOU) factor exerts the greatest effect $(+0.316)$, followed by the subjective norm (SN) factor $(+0.296)$, then the perceived usefulness (PU) factor $(+0.257)$, followed by the perceived risk (R) factor with negative total effect $(-0.147)$, while the personal innovativeness (INO) factor exerts the weakest effect $(+0.128)$. These findings of our study are in concordance with the studies of Giovanis, et al. (2012); Kalaiarasi and Srividya (2012); Wu M, et al. (2014); Bashir and Madhavaiah (2015); Fadare et al. (2016); Oruç and Tatar (2016) who have investigate the previos factors' effects, but in contrast to Yoon and Steege (2013); Kesharwani and Radhakrishna (2013), who they have shown that the social influance has insignificant effect on the intention to adopt the internet banking services.

- It is further noted that the subjective norm $(\mathrm{SN})$ factor $(\mathrm{SN}->\mathrm{PU}=0.456)$ exerts a greater effect on the perceived usefulness compared to the perceived ease of use (PEOU) factor (PEOU $->$ PU $=0.401$ ).

- The previous results showed that even though the participants appreciate the benefits of the online banking they would rather use clear and easy-to-use websites, adding to that their assessments of the usefulness of these services are significantly influenced by the surrounding people's views and prior experience.

- The reluctant effect of the perceived risk factor (R) appears to be lower than the positive effects of the perceived usefulness, perceived ease of use (PEOU)and the subjective norm $(\mathrm{SN})$, which means participants tend to weigh more the expected advantages, the convenience of this services, and the surrounding people's opinions.

- The personal innovativeness (INO) factor seems to have the least exerts among the proposed factors.

Based on the above results it is suggested that continuous efforts should be made by bank managers to improve the usability of their website. The manager may ensure that customers are provided with a clear user-friendly guide. Developing an effective advertising campaign has appealing content with offers or services that would create value for clients and increase the awareness about such services. These actions can increase the perceived usefulness of the internet banking service and persuade the customer to adopt this type of services. Furthermore, the proposed model in this study can explain about $44.4 \%$ of the variances of the internet banking adoption decision in North Cyprus. This specifies the need for other factors to be included in the prospect studies. 
In this connection, the following factors need to be addressed in the forthcoming studies; the customer satisfaction with the conventional services, the awareness about the electronic commerce regulations.

\section{Endnotes}

${ }^{1}$ It is used in the case of non-normal data, bootstrapping technique can be summarized as a resampling method, by which numbers of subsamples are generated through a random dropping and replacing sets of observations from the original data in order to derive the entire distributions and enable the significance tests (Ringle, C. M. et al., 2015).

${ }^{2}$ an iterative process starts with determining an omission distance which is usually recommended to be 7 observations, that means the blindfolding process will be repeated 7 times. This technique can be described as follow: starting from the first data in the targeted construct's indicators, each seventh point will be droped and replaced with the indicator's mean value until the end of the observations, then the PLS algorithm will be run to estimate the path coefficient, the obtained estimatations will be used to predict the dropped data points, later a comparison between the predicted values with the original observations (the dropped data points) will be conducted to calculate the differences and use it as inputs of $\mathrm{Q}^{2}$ (i.e. Sum of squares of observations $\mathrm{SSO}$ and Sum of squared prediction errors SSE (Ringle et al., 2015); Tenenhaus, 2005).

\section{Appendix}

Table 20 The study questionnaire

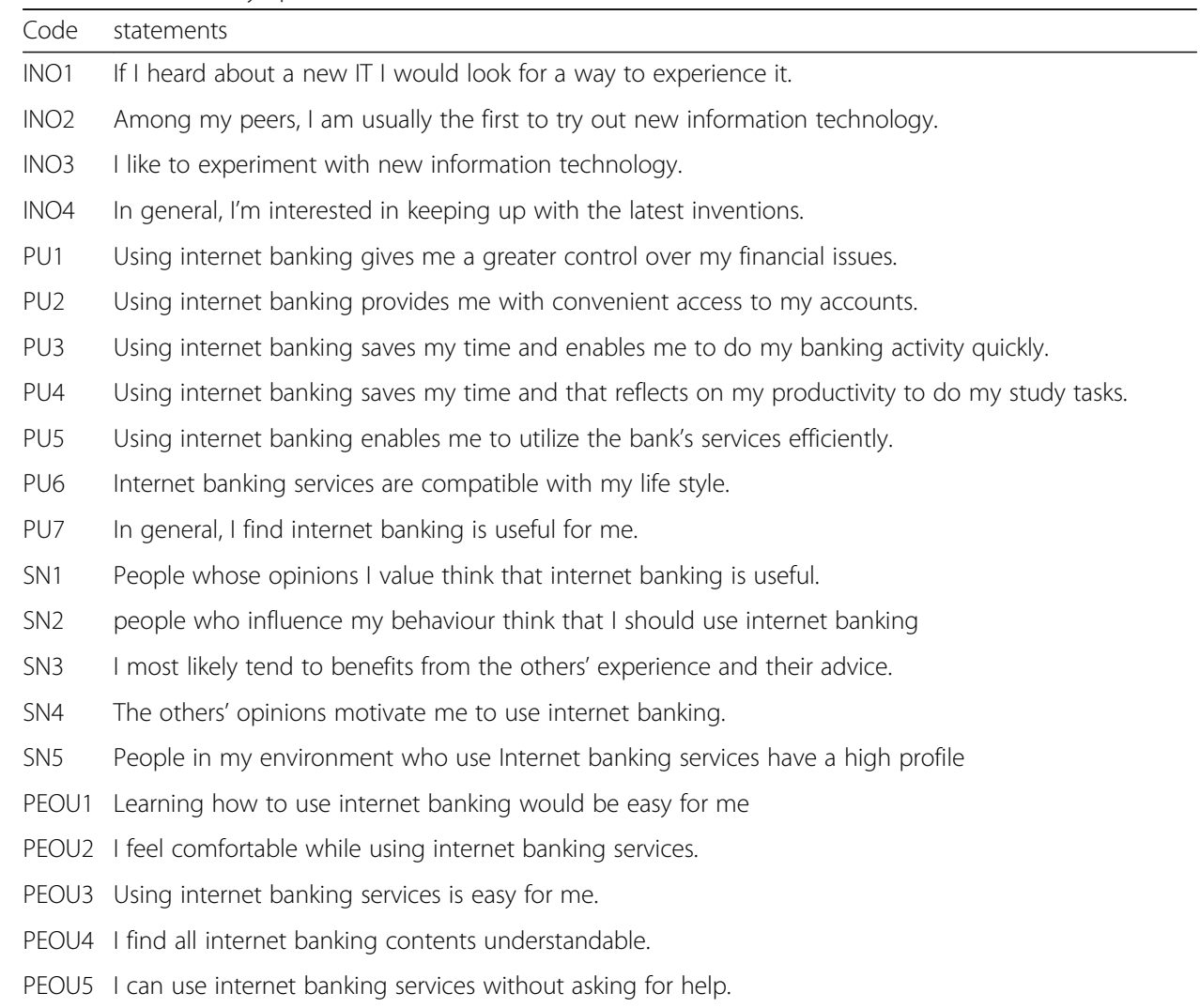


Table 20 The study questionnaire (Continued)

\begin{tabular}{ll}
\hline Code & statements \\
\hline PEOU6 & I think the easy use of the internet banking services makes it more useful. \\
R1 & Internet banking services may not perform very well and cause problems with my credit. \\
R2 & Internet banking server may not perform well and thus process payment incorrectly. \\
R3 & There is a chance to lose money if I use internet banking services. \\
R4 & Using internet banking to pay my bills may cause a sort of financial losses or problems. \\
R5 & fixing payments errors after using internet banking may require a long time Thus reducing the \\
R6 & convenience of these services \\
R7 & I am worried that third parties would steal my username and password. \\
R8 & I think that the password generating and distributing process is well secured. \\
R9 & I think that it would be risky if I use Internet banking \\
IN1 & I intend to begin/continue using Internet banking in the future. \\
IN2 & I predict that I will use or continue using Internet banking \\
IN3 & I will frequently use Internet banking in the future \\
IN4 & I will recommend others to use Internet banking. \\
IN5 & I think that I will not use/continue using Internet banking in the future. \\
\hline
\end{tabular}

\section{Abbreviations}

IN: Customers' intention to adopt the internet banking services; INO: Personal innovativeness; PEOU: Perceived ease of use; PLS-SEM: Partial least square, structural equation modeling; PU: Perceived usefulness; R: Perceived risk;

SN: Subjective Norm; TAM: The technology acceptance model

\section{Acknowledgements}

We are thankful to the Editor and the anonymous referees for their most valuable suggestions that improved early version of the manuscript.

Funding

Not applicable.

\section{Availability of data and materials}

The datasets on which the conclusions of the manuscript rely on are available upon request.

\section{Authors' contributions}

HA proposed the subject. HA together with FF performed the necessary computations and statistical analysis and then highlight the results. Both the authors read and approved the final version of the manuscript.

\section{Competing interests}

The authors declare that they have no competing interests.

\section{Publisher's Note}

Springer Nature remains neutral with regard to jurisdictional claims in published maps and institutional affiliations.

\section{Author details}

${ }^{1}$ Department of Accounting and Finance, Cyprus International University, Nicosia 99040, Northern Cyprus. ${ }^{2}$ Institute of Business studies and leadership, Faculty of Business and Economics, Abdul Wali Khan University, Mardan, KP, Pakistan. ${ }^{3}$ Near East University, North Cyprus, Nicosia 10, Mersin, Turkey.

\section{Received: 21 December 2017 Accepted: 11 October 2018}

Published online: 02 November 2018

\section{References}

Al-Fahim NH (2012) Factors affecting the adoption of internet banking amongst IIUM'students: a structural equation modeling approach. J Internet Banking Commer 17(3):1

Bashir I, Madhavaiah C (2015) Consumer attitude and behavioural intention towards internet banking adoption in India. J Indian Bus Res 7(1):67-102 
Boateng H, Adam DR, Okoe AF, Anning-Dorson T (2016) Assessing the determinants of internet banking adoption intentions: a social cognitive theory perspective. Comput Hum Behav 65:468-478

Chintalapati N, Daruri VSK (2017) Examining the use of YouTube as a learning resource in higher education: scale development and validation of TAM model. Telematics and Informatics 34(6):853-860

Chuttur MY (2009) Overview of the technology acceptance model: origins, developments and future directions. Work Pap Inf Syst 9(37):9-37

Garson GD (2016) Partial Least Squares: Regression and structural equation models. Statistical Associates Blue Book Series

Giovanis AN, Binioris S, Polychronopoulos G (2012) An extension of TAM model with IDT and security/privacy risk in the adoption of internet banking services in Greece. EuroMed J Bus 7(1):24-53

Hair JF Jr, Sarstedt M, Hopkins L, Kuppelwieser VG (2014) Partial least squares structural equation modeling (PLS-SEM) An emerging tool in business research. European Business Review 26(2):106-121

Henseler J, Hubona G, Ray PA (2016) Using PLS path modeling in new technology research: updated guidelines. Ind Manag Data Syst 116(1):2-20

Henseler J, Ringle CM, Sarstedt M (2015) A new criterion for assessing discriminant validity in variance-based structural equation modeling. J Acad Mark Sci 43(1):115-135

Hulland J, Richard Ivey School of Business (1999) Use of partial least squares (PLS) in strategic management research: a review of four recent studies. Strateg Manag J 20(2):195-204

Jakobowicz, E. (2006). Understanding PLS path modeling parameters estimates: a study based on Monte Carlo simulation and customer satisfaction surveys. In COMPSTAT 2006, 17th Symposium on Computational Statistics, Rome, Italie (pp. 721-728)

Jalil MA, Talukder M, Rahman MK (2014) Factors affecting Customer's perceptions towards online banking transactions in Malaysia. J Bus Manag 20(1):25

Kalaiarasi H, Srividya V (2012) A study on factors influencing young User's online Banking Channel usage in India. J Commer Account Res 1(3):17

Kesharwani A, Radhakrishna G (2013) Drivers and inhibitors of internet banking adoption in India. J Internet Banking Commerce 18(3):1

Kesharwani A, Singh Bisht S (2012) The impact of trust and perceived risk on internet banking adoption in India: an extension of technology acceptance model. Int J Bank Mark 30(4):303-322

Kumar Sharma S, Madhumohan Govindaluri S (2014) Internet banking adoption in India: structural equation modeling approach. J Indian Bus Res 6(2):155-169

Lowry PB, Gaskin J (2014) Partial least squares (PLS) structural equation modeling (SEM) for building and testing the behavioral causal theory: when to choose it and how to use it. IEEE Trans Prof Commun 57(2):123-146

Marcoulides, G. A., \& Saunders, C. (2006). Editor's comments: PLS: a silver bullet?. MIS quarterly, iii-ix

Monecke, A., \& Leisch, F. (2012). SEM-PLS: structural equation modeling using partial least squares

Nasri W, Charfeddine $L$ (2012) Factors affecting the adoption of internet banking in Tunisia: an integration theory of acceptance model and theory of planned behavior. J High Technol Managem Res 23(1):1-14

Nitzl C, Roldán JL, Cepeda Carrión G (2016) Mediation analysis in partial least squares path modeling: helping researchers discuss more sophisticated models. Ind Manag Data Syst

Oruç ÖE, Tatar Ç (2016) An investigation of factors that affect internet banking usage based on structural equation modeling. Comput Hum Behav 66:232-235

Ozatac N, Saner T, Sen ZS (2016) Customer satisfaction in the banking sector: the case of North Cyprus. Procedia Econ Finance 39:870-878

Rawashdeh A (2015) Factors affecting adoption of internet banking in Jordan: chartered accountant's perspective. Int J Bank Mark 33(4):510-529

Ringle, C. M., Wende, S., \& Becker, J. M. (2015). SmartPLS 3. Boenningstedt: SmartPLS GmbH, https://www.smartpls.com/

Rogers EM (2003) Diffusion of innovations, 5th edn. Free Press, New York

Sekaran U (2003) Research methods for business: a skill building approach. J Educ Bus 68(5):316-317

Voorhees CM, Brady MK, Calantone R, Ramirez E (2016) Discriminant validity testing in marketing: an analysis, causes for concern, and proposed remedies. J Acad Mark Sci 44(1):119-134

Willis TJ (2008) An evaluation of the technology acceptance model as a means of understanding online social networking behavior", Theses and Dissertations, Paper 568, available at http://scholarcommons.usf.edu/etd/568

Wong KKK (2013) Partial least squares structural equation modeling (PLS-SEM) techniques using SmartPLS. Mark Bull 24(1):1-32

Wu M, Jayawardhena C, Hamilton R (2014) A comprehensive examination of internet banking user behaviour: evidence from customers yet to adopt, currently using and stopped using. J Mark Manag 30(9-10):1006-1038

Yoon HS, Steege LMB (2013) Development of a quantitative model of the impact of customers' personality and perceptions on internet banking use. Comput Hum Behav 29(3):1133-1141

Yousafzai SY (2012) A literature review of theoretical models of internet banking adoption at the individual level. J Financ Serv Mark 17(3):215-226 